\title{
Evaluating English Language Teachers' Efficiency by Tertiary Level Male and Female Learners: A Bangladeshi Perspective
}

Marium Jamila*

Assistant Professor, Dept. of Languages, Bangladesh Agricultural University, Mymensingh, Bangladesh

DOI: $10.36348 /$ sijll.2020.v03i10.002

| Received: 11.10 .2020 | Accepted: 25.10 .2020 | Published: 30.10 .2020

*Corresponding author: Marium Jamila

Abstract

The most talented and wise teachers with a lot of training and expertise in most cases become unable to contribute effectively in developing learners' skills when unfortunately their teaching styles do not meet learners' needs. So, it is definitely important to evaluate teachers' teaching styles by the learners for getting clear conception about teaching effectiveness. Though this is not the only means of assessing effective teaching, it is still an unavoidable concept where the reflections provided by both male and female learners require to be considered equally and accordingly. Universally, every individual is unique in his/her thinking with certain differences and sometimes he/she also keeps similar understandings with others on some points - this is also true for language learners. Keeping this in mind, this paper attempted to collect the opinions of tertiary level Bangladeshi English language learners concerning their teachers' competencies with main focus on checking out whether there are thought differences or similarities between male and female learners regarding the issue. For the purpose of the study, data from 99 students (39 male, 60 female) of Level-1, Semester-1 under the Faculty of Fisheries, Bangladesh Agricultural University (BAU) was collected who took part in the survey for evaluating the qualities of their existing three English language teachers.

Keywords: Male learners, female learners, English teachers, teacher evaluation.

Copyright @ 2020: This is an open-access article distributed under the terms of the Creative Commons Attribution license which permits unrestricted use, distribution, and reproduction in any medium for non-commercial use (NonCommercial, or CC-BY-NC) provided the original author and source are credited.

\section{INTRODUCTION}

As "teachers play a significant role in students' learning and intellectual development" [1] so, besides knowing learners' needs, course evaluation or teacher evaluation should also be the primary concern of the teachers-educators in assuring the academic excellence. Usually the concept of an effective English Language teacher in Bangladeshi context is based on some aspects, like having good knowledge of English, well trained as well as having some personal traits which motivate learners for learning and using the target language. These qualities simply match with the findings of many researchers of other contexts e.g., in Ghasemi and Hashemi [2] the characteristics "such as reading and speaking proficiency, arousing students' interest in learning English, and building students' selfconfidence and motivation" (p. 414) were recognized as the basic qualities of a teacher by all of the study groups.

In the field of teaching and learning even the weakest learner is also conscious about the qualities of an effective teacher. More specifically to say, whatever the learning quality of a learner is; he/she is always a good observer of a teacher's qualities i.e. whether the teacher can teach properly or not, whether the teacher is punctual or not etc. It is a known fact that evaluation by students is not the only criterion to assess the efficiency of a good teacher, but at the same time it also holds very significant value which demands necessary consideration in teaching-learning practices. A teacher who always feels to keep himself/herself on developing cycle likes to explore learners' thought about their individual teaching strategies and for this they do not hesitate to be evaluated by the peers, seniors as well as even by the learners. Though sometimes it is a bit tough job in an English as a foreign language (EFL) context to set up the mentality of being evaluated by the learners, it is a great way to achieve clear conceptions about learners' views. Beside this, it broadens the opportunities to uphold teaching quality in order to fulfill learners' needs.

At tertiary level education in Bangladesh, keep in pace with male, female learners are increasing day by day who are also doing better in their academic and professional lives. There is no discrimination between male and female learners in teaching or learning fields and they are stepping ahead with their aims together as 
well as are equally met by teachers without any influence of gender bias. Universally it is commonly found that instead of getting similar academic facilities; both male and female learners (as different entities and individual) think and contribute on the basis of their reasoning power, individual preferences and other related issues. So, both in male and female learners' thought processes or concept building regarding either personal or academic matters, dissimilarities and sometimes also some similarities are found all over the world. This is also natural in teacher evaluation process where variations and resemblances between male and female students in assessing teachers' qualities have been revealed in different English language contexts. Following that this paper tries to find out whether Bangladeshi tertiary level male and female learners' consider their teachers' competencies mostly in parallel ways or they take these in different ways.

\section{LITERATURE REVIEW}

Language teaching differs from teaching other subject matters, especially in terms of the nature of the process where the desirable characteristics of effective language teachers are categorized by Brosh [3]: "knowledge and command of the target language"; "ability to organize, explain, and clarify, as well as to arouse and sustain interest and motivation among students"; "fairness to students"; and "availability to students" (p. 133). Santiago and Benavides [4] have found that besides knowing the aspects of teaching efficiencies it is also important to practice teacher evaluation for the purpose of "the effectiveness of teaching and learning and raise educational standards" (p. 3). Among different types of teacher evaluations (evaluation by the peer teachers, evaluation by the institution, by the learners) remarkable studies have been done on the importance of teacher evaluation by learners. According to Moreno-Murcia, Torregrosa and Pedreño [5] in order to ensure quality education at University levels all over the world different steps have been taken to evaluate teachers' performance on the basis of learners' opinions (p. 59). Whereas, Stronge [6] have noticed that the information collected through students' survey can help teachers to "reflect on their practice (i.e., for formative evaluation)" and this process dynamically serves "to provide feedback directly to the teacher for growth and development" ( $p$. 9). Like other English teaching contexts EFL contexts also feel the necessity of this strategy. According to Kassing [7], for being effective in their practices EFL teachers need to improvise dynamic teaching practices considering their classroom settings. At the same time they "should not only consider their own views of prevailing methodologies and theories in second/foreign language teaching but also determine their studentteachers' feelings about their teaching strategies" ( $p$. 124).
Some researchers have more specifically put their attention on students' gender issues in teacher evaluation process. Some researchers have found the differences between male and female students' ratings where some have revealed least or no difference in their ratings. For example, in their study Korte, Lavin and Davies [8] have unveiled the differences- “... there are specific traits which appear to be more important to females and other specific traits which appear to be more important to males" (p. 177). At the same time in the research of Ghasemi and Hashemi [2], the female learners have considered the attributes "pronunciation proficiency, teaching how to learn English, and treating students fairly" as the basic parts of teachers' efficiency and the male learners have considered "good sense of humor as important to teaching more than the female students did" (p. 414). On the other hand in the study of Wichadee [9], no significant dissimilarities between male and female groups have been noticed in the result of t-test regarding the overall perception of teachers' qualities. More clearly it has denoted that "male and female students were not different in their opinions towards characteristics of effective teachers' (P. 34).

The study of literature reveals the fact that though in most cases there are differences in male and female learners' ratings, the similarities between their concepts about effective teachers are also common in different teaching-learning contexts. As no such research has still been taken in Bangladeshi context on this issue so, this study intends to give some focus on it.

\section{METHODOLOGY}

Both male and female students of two sections of the Faculty of Fisheries, BAU provided their observation on the same day in two different English language classes. In total 99 students (excluding three scripts that were found incomplete) of level-1, semester-1 participated in this study. Among them 16 male and 27 female students were from section (Sec.) A; and 23 male and 33 female students were from Sec. B. The learners were provided with a checklist of specific teachers' characteristics which is known as $7 C s$ model of effective teaching [10]. The checklist was slightly modified and reorganized by Likert five scale options: Strongly Agree (SA), Agree (A), Undecided (U), Disagree (D), and Strongly Disagree (SD) for smooth collection of data. Before conducting the survey the necessary clarification was provided by the teacher. For ensuring spontaneous participation, learners were guided to mention only their genders without names or identity numbers. After collecting data the sheets were divided according to the genders of the participants (total four groups: one male and one female from Sec. A and one male and one female from Sec. B) and they were analyzed for the purpose of the study. The main target of the study was to find out the perceptions of male and female learners in evaluating their teachers' teaching qualities keeping some questions in mind- 
i. Do the male and female learners differ in rating their teachers' efficiency?

ii. Do the male and female learners keep similarities in evaluating teachers' performance?

iii. Do only the genders of the learners affect the evaluation process or some other aspects also play role in the evaluation process?

\section{FINDINGS AND DISCUSSION}

In the methodology part it has already been mentioned that this study has used 7Cs model of effective teaching which consists of seven specific effective teaching attributes. For more comprehensible and smooth discussion purpose it seems necessary to have some clear conception on these specific attributes before turning to the discussion part on the findings of this study.

\section{1) General Discussion on Teachers'Attributes:}

The first attribute of the checklist (AppendixA) is "Care". This attribute is considered important by $\mathrm{Ng}$. [11] who finds that "genuine caring for all students" is undoubtedly important for successful language learning (p. 117). Teachers' supportive attitude and tolerance power are also felt important by Gurung and Abdullah [12].

The second attribute is "Control". The necessity of this aspect for effective teaching strategy has been discussed by Choudhury [13] in this way: for ensuring interactive classroom teachers have to avoid the mode of teacher centered teaching styles and to exercise learner centered activities. And during interactive classroom sessions the teachers need to play the role of "a controller and a facilitator rather than of an authoritarian". The fact is that without letting learners totally on their own practices there must have some control from teachers' corner who can guide them in completing language tasks (p. 78).

The third attribute of the checklist is "Clarify" which puts focus on teachers' clear explanation of the subject matter. It is the responsibility of good teachers to prepare the lessons on the basis of learners' preference and necessity. To be effective in teaching strategy, teachers should teach the lessons rationally by understanding learners' needs and thus support learners with diverse mode of learning techniques which can help them to understand the subjects through grasping teachers' explanation properly [3]. In the study of Delaney, Johnson, Johnson and Treslan [14] the student participants have expected their teachers to be very apt in delivering lectures with meaningful and clear presentation skills (p.13).

The fourth aspect is "Challenge" which aims to know whether the learners get the scopes to learn through correcting their mistakes in every classes or not. Though effective EFL teachers should not always keep busy in finding mistakes of learners, sometimes it is also necessary to deal with the mistakes carefully. To effectively manage the mistakes of learners teachers can consider "errors as indicators of active participation in learning process, and decide how serious an error is" i.e. instead of taking silly mistakes more seriously teachers should put emphasis on correcting learners' basic mistakes that can hamper the development of learning target language. So, teachers need to apply different error correction techniques on the basis of learners' levels and learning contexts very cautiously [15].

The fifth attribute is "Captivate" which intends to check whether the students like teachers' teaching processes or not i.e. how much interesting are the lessons. In the study of Rasyid [16], the participants have expected interesting and less stressful learning environment where they can comfortably learn the language and they have also mentioned that it is the task of the teachers to offer such environments (p. 81). $\mathrm{Ng}$ [11] feels that teachers should apply different games and fun based language activities where these activities which need to be designed in such a way that makes each and every student (including the less enthusiastic one) active in doing the tasks (p. 45).

The sixth aspect of the model is "Confer" which intends to examine whether teachers value students' ideas or not. Teachers who are good listeners to students' problems are also considered as effective teachers. When students find that teachers listen to their problems and take the matters seriously, these work as motivational factors for them. Through regular teacherstudent interaction the classroom gets the real reflection of communicative classroom [17]. At the same time, students also feel confident when they find their problems and concepts are importantly taken by the teachers and thus they gradually become responsible in shaping their own learning stages with active participation in classroom practices [18].

The seventh (and the last) aspect is "Consolidate". Besides being co-operative in learners' needs, teachers also need to be sure about whether their lessons are perceived properly by the learners or not as well as whether the teaching techniques can help learners for further improvement or not. $\mathrm{Ng}$. [11] believes that in addition to increasing knowledge on effective measures of teaching, teachers must be aware of the issues which create obstacles before learners for stepping forward. He also feels that language teachers should have the capability and mentality "to step inside a student's shoes" with an aim to realize "what the student is going through learning a language... That means teachers can use their experiences of being a language learner to better understand how their students are experiencing their classroom practices" (p. 114$115)$. 


\section{2) Main Discussion on the Findings}

Students of two sections have evaluated their existing three English language teachers' (two male and one female) in two different classes on the same day. As the study aims to take care of the gender issue of the students for evaluating teachers' performance so, contribution of the participants have been analyzed using teacher specific tables and charts. Only qualities of each teacher which were mentioned by most of the male and female students of these two sections have been taken into consideration here for the discussion.
Teacher-1

The findings revealed that among all four groups of male and female learners, the attribute "Confer" was marked by the three groups (Male-Sec. A, B and Female- Sec. A) as the top most quality of the first teacher. In total $94 \%$ male students of Sec. A, $100 \%$ male students of Sec. B and $100 \%$ female students of Sec. A agreed that the teacher had this specific attribute. Whereas, $100 \%$ female students of Sec. B chose "Control" as the best attribute of teacher-1.

Table-1: Top most quality of teacher-1 addressed by the students (on the basis of their gender)

\begin{tabular}{|c|c|c|c|c|c|}
\hline $\begin{array}{l}\text { Gender of the } \\
\text { Students }\end{array}$ & $\begin{array}{l}\text { Section } \\
\text { (Sec.) }\end{array}$ & $\begin{array}{l}\text { Total } \\
\text { students }\end{array}$ & $\begin{array}{l}\text { Attribute that was marked } \\
\text { positively highest time }\end{array}$ & $\begin{array}{l}\text { Agreed by the } \\
\text { number of students }\end{array}$ & $\begin{array}{l}\text { Percentage } \\
(\%)\end{array}$ \\
\hline \multirow[t]{2}{*}{ Male } & $\mathrm{A}$ & 16 & Confer & 15 (14-SA, 1-A) & $94 \%$ \\
\hline & $\mathrm{B}$ & 23 & Confer & 23 (18-SA, 5-A) & $100 \%$ \\
\hline \multicolumn{6}{|c|}{ and } \\
\hline \multirow[t]{2}{*}{ Female } & $\mathrm{A}$ & 27 & Confer & 27 (23-SA, 4-A) & $100 \%$ \\
\hline & $\mathrm{B}$ & 33 & Control & 33 (26-SA, 7-A) & $100 \%$ \\
\hline
\end{tabular}

Now, instead of dissimilarities between male and female students, mostly the similarities between their thinking while evaluating the first teacher have been revealed as both sections of male and one section of female strongly agreed upon the same attribute.

\section{Teacher- 2}

Here, the attribute "Care" was chosen by the majority of the two groups of male and female students
(Male-Sec B, Female- Sec. A) while agreed upon the best quality of second teacher. In total $96 \%$ males of Sec. B and $100 \%$ females of Sec. A agreed that this quality was more apparent in teacher-2. Whereas, 100\% males of Sec. A found the attribute "Confer" and 100\% females of Sec. B found the attribute "Consolidate" more prominent in the same teacher.

Table-2: Top most quality of teacher-2 addressed by the male and female students

\begin{tabular}{|l|l|l|l|l|l|}
\hline $\begin{array}{l}\text { Gender of the } \\
\text { Students }\end{array}$ & $\begin{array}{l}\text { Section } \\
\text { (Sec.) }\end{array}$ & $\begin{array}{l}\text { Total } \\
\text { students }\end{array}$ & $\begin{array}{l}\text { Attribute that was marked } \\
\text { positively highest time }\end{array}$ & $\begin{array}{l}\text { Agreed by the number } \\
\text { of students }\end{array}$ & $\begin{array}{l}\text { Percentage } \\
(\%)\end{array}$ \\
\hline \multirow{2}{*}{ Male } & A & 16 & Confer & $16(15-S A, 1-A)$ & $100 \%$ \\
\cline { 2 - 6 } & B & 23 & Care & $22(20-S A, 2-A)$ & $96 \%$ \\
\hline \multirow{7}{*}{ Female } & A & 27 & Care & $27(26-S A, 1-A)$ & $100 \%$ \\
\cline { 2 - 6 } & B & 33 & Consolidate & $33(29-S A, 4-A)$ & $100 \%$ \\
\hline
\end{tabular}

The above findings denote that among all four groups of male and female students, one group of male and one group of female found the same quality as the best one for teacher- 2 and rest of the two groups of male and female students brought out different individual attributes. At this point, some related questions naturally arise: Does only gender difference affect teacher effectiveness? or, Are there some other considerations that also affect the evaluation process like teachers' genders, their teaching styles, class time, students' learning styles etc.?

\section{Teacher-3}

Among all four groups of male and female learners, the aspect "Clarify" was defined as the top most quality of the $3^{\text {rd }}$ teacher by $100 \%$ male students of Sec. A and $91 \%$ of Sec. B and $85 \%$ female students of Sec. B. whereas $93 \%$ female students of Sec. A agreed upon the attribute "Captivate" as the best quality of teacher- 3 .

Table-3: Top most quality of teacher-3 addressed by two sections of male and female students

\begin{tabular}{|l|l|l|l|l|l|}
\hline $\begin{array}{l}\text { Gender of } \\
\text { the Students }\end{array}$ & $\begin{array}{l}\text { Section } \\
\text { (Sec.) }\end{array}$ & $\begin{array}{l}\text { Total } \\
\text { students }\end{array}$ & $\begin{array}{l}\text { Attribute that was marked } \\
\text { positively highest time }\end{array}$ & $\begin{array}{l}\text { Agreed by the } \\
\text { number of students }\end{array}$ & Percentage (\%) \\
\hline \multirow{2}{*}{ Male } & A & 16 & Clarify & $16(15-\mathrm{SA}, 1-\mathrm{A})$ & $100 \%$ \\
\cline { 2 - 6 } & $\mathrm{B}$ & 23 & Clarify & $21(17-\mathrm{SA}, 4-\mathrm{A})$ & $91 \%$ \\
\hline \multicolumn{7}{|l|}{ and } & $25(20-\mathrm{SA}, 5-\mathrm{A})$ & $93 \%$ \\
\hline Female & $\mathrm{A}$ & 27 & Captivate & $28(24-\mathrm{SA}, 4-\mathrm{A})$ & $85 \%$ \\
\cline { 2 - 6 } & $\mathrm{B}$ & 33 & Clarify & \\
\hline
\end{tabular}


Coming to this part, (along with some differences) again mostly similarities between male and female students' ratings have been noticed. As well as, the difference is not limited between male and female students, dissimilarities between two groups of females have also been found clear (like the teacher-1).

\section{3) Summary of the Discussion}

In this study differences as well as similarities between tertiary level male and female learners in rating their teachers' effectiveness have been revealed. The study has also exposed that these differences exist not only between male and female; but also among male to male and female to female depending on sections/groups of the students. At the same time though some distinct differences between male and female students' rating styles (especially in percentage form) are clearly noticeable, still in bringing out their existing language teachers' efficiency, they have shared more or less some common ground where they have put emphasis on the teachers' common attributes like care, clarify, confer etc. Here, in addition to their genders other issues like the genders of the teachers, their teaching styles, time of teaching etc. also put effect on the process of students' ratings. This finding is very similar with the finding of Young, Rush and Shaw [19]. They have found that "student ratings differ according to instructor characteristics, student characteristics, and course characteristics" (p. 2). Besides in this study, learners' individual preference regardless of their gender is clearly observable where they have judged their teachers through their every single mind. As a result every individual teacher gets specific positions from the corner of the students' satisfaction levels. Another important observation is that in most cases female students are more moderate than the male students in discovering the efficiency of their teachers. For that reason, the combined result of both sections discovers that among three teachers two of them (Techer-1 and Teacher-2) have got the highest ratings/percentage from their female students in comparison to the male students. This matches the idea, "females in general tend to rate teachers higher in terms of contributions to teaching effectiveness" [8]. So, by considering the qualities preferred by both male and female learners, teachers can also modify their teaching styles. But while considering students' ratings for designing lesson plans teacher should be very cautious as there are different dynamic variations in their perceptions of effective teaching [20].

\section{LIMITATIONS AND RECOMMENDATIONS}

Inclusion of large number of students was necessary to take into account for more reliable findings. At the same time, the qualities of the teachers which were marked lowest also needed to be analyzed for further clarification as it might be concluded that students can identify with some consistency the positive traits they appreciate in an instructor but are not as certain of the traits that are less effective for good teaching" [21]. Thus further studies are expected to get more in-depth result on this issue as well as on how students' ratings can be utilized in designing effective course curriculum.

\section{CONCLUSION}

Teachers' positive qualities are always accepted and honored by learners regardless of their gender. However, as universally male and female students are distinct in nature so, usually in most cases they evaluate their teachers in different ways. The study has also explored the similar finding in their judgments on teachers' efficiencies. This study has also revealed that there exist not only differences but also some similarities in the evaluation process and there are some other related teaching-learning practices that influence the rating strategies. For this "when designing lessons or when providing instructions, effective English teachers should take students' gender as well as academic achievement into consideration" [22]. If this can be ensured (broadening the mentality of accepting students' ratings on the basis of their genders and other connected issues avoiding the traditional mindset) by the teachers of Bangladesh, expected outcomes of effective teaching will be achieved successfully.

\section{REFERENCES}

1. Hashim, N.M.H.N., Alam, S. S., \& Yusoff, N.M. (2014). Relationship between Teacher's Personality, Monitoring, Learning Environment, and Students' EFL Performance. GEMA Online ${ }^{\circledR}$ Journal of Language Studies, 14(1), 101-116.

2. Ghasemi, B., \& Hashemi, M. (2011). The study of the characteristics of successful English language teachers from the view point of the English language students of Islamic Azad University, Hamedan Branch. Procedia-Social and Behavioral Sciences, 28, 411-415.

3. Brosh, H. (1996). Perceived Characteristics of the Effective Language Teacher. Foreign Language Annals, 29(2), 125-136.

4. Santiago, P., \& Benavides, F. (2009). Teacher evaluation: A conceptual framework and examples of country practices. Paper presented at the OECD, Mexico City, 1-2 December.

5. Moreno-Murcia, J. A., Torregrosa, Y. S., \& Pedreño, N. B. (2015). Questionnaire evaluating teaching competencies in the university environment. Evaluation of teaching competencies in the university. Journal of New Approaches in Educational Research, 4(1), 54-61.

6. Stronge, J. H. (2012). Stronge teacher effectiveness performance evaluation system. Williamsburg, VA: Stronge \& Associates Educational Consultants, LLC.

7. Kassing, R. B. (2011). Perceptions of motivational teaching strategies in an EFL classroom: The case of a class in a private university in Indonesia. M.A. 
Thesis, Victoria University of Wellington, New Zealand.

8. Korte, L., Lavin, A., \& Davies, T. (2013). Does Gender Impact Business Students' Perceptions Of Teaching Effectiveness? Journal of College Teaching \& Learning, 10(3), 167-178.

9. Wichadee, S. (2010). Defining the effective English language teacher: Students' and teachers' perspectives. In A. M. Stoke (Ed.), JALT2009 Conference Proceedings. Tokyo: JALT.

10. Kane, T. J., \& Cantrell, S. (2010). Learning about teaching: Initial findings from the measures of effective teaching project. MET Project Research Paper, Bill \& Melinda Gates Foundation, 9, 2010.

11. Ng, Y. Y. C. (2003). What makes a 'Good Language Teacher'? Teachers' and students' perceptions of 'Good Language Teachers' in Hong Kong secondary schools. Unpublished MEd. Thesis, the University of Hong Kong, Hong Kong.

12. Gurung, H.B., \& Abdullah, R. (2007). Motivation: Its Crucial Role in Teaching English in Class Rooms. Daffodil International University Journal of Business and Economics, 2 (1).

13. Choudhury, S. (2005). Interaction in Second Language Classrooms. BRAC University Journal, 2(1), 77-82.

14. Delaney, J.G., Johnson, A. N., Johnson, T. D., \& Treslan, D. L. (2010). Students' Perceptions of Effective Teaching in Higher Education. St. John's, NL: Distance Education and Learning Technologies, Boards of Regents of the University of Wisconsin System.
15. Aydogdu, E. (2007). EFL teachers' perceptions foreign language teaching competences. Master Thesis, Trkya University.

16. Rasyid, M.N.A. (2014). The Charecteristics of Effective EFL Teachers as perceived by Students: A Study at Uni Alauddin Makassar. Jurnal Al Hikmah, 4(1)

17. Mielnik, S. (2012 Oct). The Importance of Good Teacher-Student Relations. Retrieved 15 May 2017 from

https://www.englishclub.com/efl/teflarticles/teache r-student- relations/

18. Pahlavannejad, M.R., \& Bostani, H.N. (2013). The Role of EFL Teachers in Increasing High School Students' Motivation in Classroom. International Journal of Education and Research, 1(10).

19. Young, S., Rush, L., \& Shaw, D. (2009). Evaluating Gender Bias in Ratings of University Instructors' Teaching Effectiveness. International Journal for the Scholarship of Teaching and Learning, 3(2), 19.

20. Zare-ee, A., Mohd Don, Z., \& Tohidian, I. (2016). Gender differences in students' ratings of university teachers in the Iranian education system. Learning and Teaching in Higher Education: Gulf Perspectives, 13(1).

21. Lavin, A., Korte, L., \& Davies, T. (2012). Student Gender and Perceptions of Teaching Effectiveness. Research in higher education journal, 18.

22. Chen, Y. J., \& Lin, S. C. (2009). Exploring Characteristics for Effective EFL Teachers from the Perceptions of Junior High School Students in Tainan. STUT Journal of Humanities and Social Sciences, 2, 219-249.

\begin{tabular}{|l|l|}
\hline CONSTRUCT & \multicolumn{1}{c|}{ Appendix-A } \\
\hline Care & My teacher in this class makes me feel that s/he really cares about me. \\
\hline Control & Students in this class treat the teacher with respect. \\
\hline Clarify & My teacher explains difficult things clearly. \\
\hline Challenge & In this class, we learn to correct our mistakes. \\
\hline Captivate & I like the ways we learn in this class. \\
\hline Confer & Students speak up and share their ideas about class work. \\
\hline Consolidate & My teacher checks to make sure we understand what s/he is teaching us. \\
\hline
\end{tabular}

7Cs model of Teaching Effectiveness (on the basis of Kane and Cantrell, 2010) 